\title{
(息)
}

Citation:

Ashley, L (2021) Unilateral Coercive Measures: Towards International Humanitarian Law and International Human Rights. In: Unilateral Sanctions in International Law. Hart Publishing. ISBN 9781509948383, 9781509948406

Link to Leeds Beckett Repository record:

https://eprints.leedsbeckett.ac.uk/id/eprint/7481/

Document Version:

Book Section (Accepted Version)

The aim of the Leeds Beckett Repository is to provide open access to our research, as required by funder policies and permitted by publishers and copyright law.

The Leeds Beckett repository holds a wide range of publications, each of which has been checked for copyright and the relevant embargo period has been applied by the Research Services team.

We operate on a standard take-down policy. If you are the author or publisher of an output and you would like it removed from the repository, please contact us and we will investigate on a case-by-case basis.

Each thesis in the repository has been cleared where necessary by the author for third party copyright. If you would like a thesis to be removed from the repository or believe there is an issue with copyright, please contact us on openaccess@leedsbeckett.ac.uk and we will investigate on a case-by-case basis. 


\section{Unilateral Coercive Measures: Towards International Humanitarian Law and International Human Rights \\ Louisa Ashley}

\section{Introduction}

The use of coercive measures including economic sanctions has been favoured by certain, predominantly Western, states as an alternative to the use of armed force, asserting pressure to effect change at arm's length via an apparently non-lethal use of force. Yet the assumption that the use of economic sanctions presents 'non-lethal' and 'non-destructive' solutions is a misapprehension. ${ }^{1}$ For the target state, the impact of multilateral and unilateral coercive measures (UCMs) on its humanitarian capacity can be long-term and devastating, and can be the cause, directly and indirectly, of the collateral damage of gross human rights and humanitarian violations.

Concerns about the humanitarian implications of comprehensive sanctions (both multilateral and unilateral) have been well rehearsed, for example, in the wake of the consequences suffered by the general population of Iraq and Haiti in the 1990s. ${ }^{2}$ The public and political outcry that followed prompted a move by the Security Council away from comprehensive measures to those designed to be 'smart' by targeting named individuals, groups, governments and organisations. ${ }^{3}$ Yet, somewhat ironically, compared to comprehensive measures, the humanitarian impact of smart sanctions has been said to be more difficult for the target state to circumvent because they are more difficult to 'cheat'. ${ }^{4}$

\footnotetext{
${ }^{1}$ WM Reisman and DL Stevick, 'The Applicability of International Law Standards to United Nations Economic Sanctions Programmes' (1998) 9 European Journal of International Law 86, 95.

2 See, eg, DW Drezner, 'Sanctions Sometimes Smart: Targeted Sanctions in Theory and Practice' (2011) 13 International Studies Review 96, 97-99; ME O’Connell, 'Debating the Law of Sanctions' (2002) 13 European Journal of International Law, 59; and WM Reisman, 'Assessing the Lawfulness of Non-military Enforcement: The Case of Economic Sanctions’ (1995) 89 American Society of International Law Proceedings 350.

${ }^{3}$ UNSC 'Speakers for Clearer Definition, Tighter Targeting of UN Sanctions as Council Draws on 'lessons learned' to Refine Sanctions' (17 April 2000) Press release SC/6845.

${ }^{4}$ O'Connell, 'Debating the Law of Sanctions' (2002) 79, citing 'US Plan for Smart Sanctions must be "Nipped in the Bud”, Iraq', Agence Fr Press (14 May 2001) 2001 WL 2405528.
} 
Contemporary use of UCMs has followed the Security Council's move away from comprehensive sanctions to targeted measures. UCMs are a source of controversy for a number of reasons, for example: they fall outside of the scope of the United Nations Charter; they are not authorised by relevant UN bodies; and they contravene 'the basic principles of the multilateral trading system' ${ }^{5}$ Concerns persist about the legality of such unilateral measures and that they negatively impact the socioeconomic development of developing countries. ${ }^{6}$ Whilst ostensibly designed to 'apply pressure to bring about a change in the conduct of the target', ${ }^{7}$ their impact can result in significant collateral damage to the socioeconomic status and basic human rights of the broader population. ${ }^{8}$ Direct and indirect effects include disrupting and destabilising supply chains for the provision of essential services and supplies, including power, medical supplies and foodstuffs, and limiting access to healthcare and education, as well as threatening the right to life and breaching the individual human rights of named subjects. ${ }^{9}$

UCMs are taken in this chapter to be sanctions imposed by one state, or by a regional body of states (such as the EU), against another in response to an alleged breach by the target state of its obligations under international law. ${ }^{10}$ The primary focus is upon economic UCMs, defined as

measures of an economic - as contrasted with diplomatic or military - character taken by states to express disapproval of the acts of the target state or to induce that state to change some policy or practice or even its governmental structure. ${ }^{11}$

\footnotetext{
${ }^{5}$ UNGA Report of the Secretary-General, 'Unilateral economic sanctions as a means of political and economic coercion against developing countries’ (2017) UN Doc A/72/307, para 1.

6 ibid. Although, as Surya Subedi notes in this collection, the argument that the use of UCMs is by developed nations against developing is weakened by the imposition of measures against Qatar and Syria by other developing Arab states.

${ }^{7}$ V Lowe and A Tzanakopoulos, 'Economic Warfare' in R Wolfrum (ed), Max Planck Encyclopedia of Public International Law (Oxford University Press, 2012) 10.

${ }^{8}$ For a review of the broader impact of US economic sanctions requiring the disclosure by companies of certain minerals in their supply chain originating from the Democratic Republic of Congo or neighbouring countries, $\mathrm{M}$ Owen, 'The Limits of Economic Sanctions under International Humanitarian Law: The Case of the Congo' (2012) 48 Texas International Law Journal 103, 112.

${ }^{9}$ OHCHR, 'Thematic study of the Office of the United Nations High Commissioner for Human Rights on the impact of unilateral coercive measures on the enjoyment of human rights, including recommendations on actions aimed at ending such measures', (2012) A/HRC/19/33, para 27, citing European Court of Justice, Kadi Case, Joined Cases C-402/05 P and C-415/05 P, Yassin Abdullah Kadi and Al Barakaat International Foundation $v$ Council and Commission, European Court of Justice, 3 September 2008, 47 ILM 923 (2008), paras 348 and 349 , where the Court held that the applicants' rights of defence as well as their right to an effective legal remedy had in fact been infringed.

${ }^{10}$ A more detailed assessment of the definition and legality of unilateral economic sanctions and retorsion is provided elsewhere in this collection, in particular see chs 1 and 2 by Profs Surya Subedi and Nigel White respectively. For this reason, only brief consideration of these matters offered here.

${ }^{11}$ AF Lowenfeld, International Economic Law (Oxford University Press 2002) 698.
} 
The use of economic sanctions is not new. Woodrow Wilson was a proponent of them as a powerful weapon causing no injury beyond the target state; he claimed a century ago that:

A nation that is boycotted is a nation that is in sight of surrender. Apply this economic, peaceful, silent deadly remedy and there will be no need for force. It is a terrible remedy. It does not cost a life outside the nation boycotted. ${ }^{12}$

Whilst the use of UCMs may be a popular domestic solution for the imposing state, those at the mercy of the 'terrible remedy' include the broader population of the target state, despite the 'smart' nature of the sanctions imposed. In particular, 'the right to life, the rights to health and medical care, the right to freedom from hunger and the right to an adequate standard of living, food, education, work and housing' have been cited as coming under threat. ${ }^{13}$ Scholars, state representatives, and the Human Rights Council have referred to the use of UCMs as 'economic warfare'. ${ }^{14}$ The impact of certain UCM regimes has been discussed in terms of collective punishment by creating conditions of starvation amongst the civilian population, prompting accusations of the commission of a war crime under international humanitarian law (IHL). ${ }^{15}$ However, obtaining quantitative data to evidence that human rights and humanitarian law violations are a direct consequence of sanctions and not due to other factors, for example domestic mismanagement, is problematic. ${ }^{16}$

The UN Charter provides authority for the use of multilateral sanctions via the Security Council; ${ }^{17}$ however, UCMs employed by one state, or a regional group of states, are not subject to a specific and designated legal framework. In the context of this absence, scholarship on the humanitarian and human rights implications of UCMs has generally addressed fundamental principles of international humanitarian law (IHL) and international human rights law (IHR)

\footnotetext{
12 Reisman and Stevick, 'The Applicability of International Law Standards' (1998) 89, citing SK Padover (ed), Wilson's Ideals (Washington D. C.: American Council on Public Affairs 1942)

13 UNHRC Res 27/21 (2014), 'Human rights and unilateral coercive measures' (03 October 2014) A/HRC/RES/27/21.

${ }^{14}$ Lowe and Tzanakopoulos, 'Economic Warfare' (2012); ICESCR - General comment No. 8, paras 12-14; OHCHR 'Civilians Caught in Sanctions Crossfire Need Geneva Convention Protection, Says UN Expert' (8 November 2018) Press Release.

${ }^{15}$ OHCHR, 'Thematic study' (2012) para 10, citing Protocol Additional to the Geneva Conventions of 12 August 1949, and relating to the Protection of Victims of International Armed Conflicts (Protocol I), Art 54; Protocol Additional to the Geneva Conventions of 12 August 1949, and relating to the Protection of Victims of NonInternational Armed Conflicts (Protocol II), Art 14.

${ }^{16}$ R Garfield and S Santana, 'The Impact of the Economic Crisis and the US Embargo on Health in Cuba' (1997) 87 American Journal of Public Health 15, 15.

${ }^{17}$ Pursuant to Art 39 of the United Nations Charter (the Charter), there is the power for the Security Council to pass resolutions imposing 'measures not involving the use of armed force' to maintain or restore international peace and security. Those measures may, under Art 41, 'include complete or partial interruption of economic relations'.
} 
and, to a lesser degree, the law of countermeasures as encapsulated by ARSIWA (draft Articles on the Responsibility of States for Internationally Wrongful Acts). ${ }^{18}$ As White and Abass observe, the concept of countermeasures under ARISWA 'is a fairly narrow one at one end of a spectrum of non-forcible measures' whilst 'at the other end of the spectrum are sanctions undertaken by international organizations', between which 'there is something of a grey area where regulation is rudimentary, indeed, arguably, non-existent' ${ }^{19}$ It is in this in-between 'grey area' that UCMs are situated.

This chapter does not set out to debate the comparative nature of the regulatory frameworks (or lack thereof) governing multilateral sanctions imposed by international organisations, such as the Security Council, countermeasures and UCMs. This is addressed elsewhere in this collection. Rather, it provides some analysis of state practice in the use of UCMs and explores the proposition that failing their abolition, IHL principles could be applied to correct the negative effect of unilateral sanctions on the enjoyment of human rights by, for example, examining the application of principles of IHL to both the decision to impose highintensity economic UCMs, and to their impact and consequences.

Section II briefly outlines an emerging consensus of concern as to the use of UCMs, as reflected by the Human Rights Council and related mechanisms. Section III takes particular sanctions regimes as case studies to specifically address and explore the relevance and application of IHL principles. The focus is primarily on Venezuela and Iran, with illustrative reference to Cuba. Consideration is also given in this section to alternative legal recourse via the International Court of Justice (ICJ) and under the Charter of the Organization of American States (OAS). Despite the inclusion of humanitarian exceptions to the application of UCMs these are, as this section illustrates, largely ineffective.

The chapter concludes that whilst arguments against the legality of UCMs are strong, the likelihood of a move away from their use is less so. As such, the humanitarian and human rights consequences of UCMs must be governed by a legal framework that has key IHL principles at its heart and that accommodates the concept of decentralised economic warfare. Such a framework should also include the requirement for a human rights / humanitarian

18 See, eg: A Hofer, 'The Developed/Developing Divide on Unilateral Coercive Measures: Legitimate Enforcement or Illegitimate Intervention?' (2017) 16(2) Chinese Journal of International Law 175; Lowe and Tzanakopoulos (n 7); O'Connell (n 2); ND White and A Abass, 'Countermeasures and sanctions' in M Evans, International Law, 5th edn (Oxford University Press, 2018).

${ }^{19}$ White and Abass (ibid) 524. 
impact assessment to be conducted before the deployment of UCMs. Without the creation of such a framework, there remains the option for the use of economic UCMs to be outlawed entirely.

\section{The Position of the Human Rights Council}

The Human Rights Council has become increasingly vocal in respect of the use of UCMs, indicating disquiet and sharing the concerns held by numerous states as to the motivations for their use and impact. This reflects a change in the focus of scholarship in respect of UCMs. As Mary Ellen O'Connell explains, the latter part of the 1960s was characterised by discussion of the lawfulness or otherwise of economic sanctions imposed by the UN. In the 1990s, the debate moved to the effectiveness of economic sanctions as a means to promote human rights and democracy. More recently, the focus has been upon an assessment of the human rights and humanitarian implications of the use of such measures. ${ }^{20}$

The Human Rights Council defines UCMs as including, but not limited to, 'economic or political measures, to coerce another State in order to obtain from it the subordination of the exercise of its sovereign rights and to secure from it advantages of any kind' ${ }^{21}$ In 2012, the High Commissioner for Human Rights reminded states that their actions 'in the international arena must be consistent with customary international law principles and the Charter of the United Nations as also interpreted by the International Court of Justice' and that states must refrain 'from adopting unilateral coercive measures that breach their human rights obligations under treaty or customary international law'. ${ }^{22}$ Furthermore, states 'should avoid the application of any coercive measures having negative effects on human rights, particularly on the most vulnerable' and that 'essential supplies, such as medicines and food, are not used as tools for political pressure, and that under no circumstances should people be deprived of their basic means of survival'. ${ }^{23}$

\footnotetext{
${ }^{20}$ O’Connell (n 2).

${ }^{21}$ UNHRC Res 27/21 (2014) (n 13). This approach echoes Art 20 of the OAS Charter, which requires that 'No State may use or encourage the use of coercive measures of an economic or political character in order to force the sovereign will of another State and obtain from it advantages of any kind'.

${ }^{22} \mathrm{OHCHR}$ (n 9) paras 39-40.

${ }^{23}$ OHCHR (n 9) paras 41-42.
} 
Building upon these recommendations, two years later the Council unequivocally called for states to stop using UCMs, stressing that 'unilateral coercive measures and legislation are contrary to international law, international humanitarian law, the Charter and the norms and principles governing peaceful relations among States'. ${ }^{24}$ The wording of the 2014 resolution follows much of the wording in a draft resolution proposed the year before by Iran (on behalf of the non-aligned movement) and the State of Palestine (on behalf of the Group of Arab States). ${ }^{25}$ That such a draft resolution would be sponsored by Iran and Palestine is not surprising - each has a vested interest being targets of sanctions by the US and others. ${ }^{26}$

The final resolution (in tandem with the draft) states that economic UCMs 'can have far-reaching implications for the human rights of the general population of targeted States, disproportionately affecting the poor and the most vulnerable classes', and that long-term measures 'may result in social problems and raise humanitarian concerns'. It calls for states to stop 'adopting, maintaining or implementing unilateral coercive measures' that are not 'in accordance with international law, international humanitarian law, the Charter of the United Nations and the norms and principles governing peaceful relations among States'. ${ }^{27}$ It proceeds to state the negative impact upon a variety of rights including 'the right to life, the rights to health and medical care, the right to freedom from hunger and the right to an adequate standard of living, food, education, work and housing'.

The growing concern of the impact of UCMs is further illustrated by the creation of the position of Special Rapporteur on the Negative Impact of Unilateral Coercive Measures on the Enjoyment of Human Rights. ${ }^{28}$ The first appointee to this role (in May 2015), Idris Jazairy, called for the international community to give this 'form of warfare that relies on starvation and disease' the same concern as any other conflict would warrant. ${ }^{29}$ Subsequent Human Rights Council resolutions and endorsed reports reflect the mounting concern for the impact of

\footnotetext{
${ }^{24}$ UNHRC Res 27/21 (2014) (n 13) preamble.

${ }^{25}$ UNHRC Draft Res 'Human rights and unilateral coercive measures' (24 September 2013) A/HRC/24/L.5/ Rev.1.

26 See US Treasury Department: sanctions against Palestine, available at https:/home.treasury.gov/policyissues/financial-sanctions/sanctions-programs-and-country-information/counter-terrorism-sanctions/palestinianauthority; and sanctions against Iran, available at https://home.treasury.gov/policy-issues/financialsanctions/sanctions-programs-and-country-information/iran-sanctions.

${ }^{27}$ UNHRC Res 27/21 (2014) (13) para 1.

${ }^{28}$ This position was initially held by Mr Idriss Jazairy (Algeria). Ms Alena Douhan (Belarus) was appointed in March 2020; see www.ohchr.org/EN/Issues/UCM/Pages/SRCoerciveMeasures.aspx.

${ }^{29}$ OHCHR, 'Civilians Caught in Sanctions Crossfire' (2018).
} 
UCMs on human rights. In a joint communique in 2016, Russia, China and India came together to denounce the far-reaching and negative impact of unilateral sanctions:

[T] he imposition of unilateral sanctions, which exceed the ones agreed by the United Nations Security Council, is inconsistent with principles of international law, undermines the prerogatives of the United Nations Security Council as set forth in the UN Charter, reduces effectiveness of its sanctions regimes, disproportionally affects States against which they are imposed, as well as, when applied extra-territorially, has a negative impact upon third States and international trade and economic relations at large. Good-faith implementation of principles of sovereign equality of States, non-intervention in the internal affairs of States and cooperation excludes imposition of unilateral coercive measures not based on international law. ${ }^{30}$ (emphasis added)

The final words of this statement - 'not based on international law' - are central to the determination of the lawfulness of measures taken. In the CJEU case of Centro-Com, the Court ruled that Member States were permitted to only take measures contrary to EU law when seeking to comply with mandatory Security Council resolutions. ${ }^{31}$ This of itself casts doubt upon the legality of measures adopted by individual EU Member States on an autonomous basis. This is notwithstanding the arguments pursued below that the lawfulness of UCMs should be determined by developing a regulatory / governance regime that incorporates key IHL principles to mitigate the detrimental and often severe impact upon fundamental rights and freedoms.

Under Article 49 ARSIWA, countermeasures must be proportionate and taken as a means of inducement, not punishment. ${ }^{32}$ Furthermore, 'if they are effective in inducing the responsible State to comply with its obligations of cessation and reparation, they should be discontinued and performance of the obligation resumed'. ${ }^{33}$ As section III illustrates, principles of proportionality and inducement are apt for application to the governance and regulation of UCMs. They ought also to be considered in tandem with two further pertinent questions. Firstly, what of those measures that are not effective at inducing compliance? Secondly, what of those UCMs whereby the impact is disproportionate and indiscriminate vis-a-vis the (alleged) actions / omissions of the targeted state? These questions assist with determining how key principles of IHL can be engaged and relied upon when addressing the lawfulness or otherwise of the impact of UCMs upon the civilian population.

\footnotetext{
${ }^{30}$ Joint Communique' of the 14th Meeting of the Foreign Ministers of the Russian Federation, the Republic of India and the People's Republic of China (19 April 2016), para 6, available at www.fmprc.gov.cn/mfa_eng/wjdt_665385/2649_665393/t1356652.shtml.

${ }^{31}$ ECR I-00081The Queen, ex parte Centro-Com Srl v HM Treasury and Bank of England (1997).

${ }^{32}$ ARSIWA, Commentary to Art 49, para 6.

33 ibid, para 7 .
} 


\section{Applying IHL Principles to UCM Regimes: Case Studies}

This section considers the current use of UCMs against two states, Venezuela and Iran, with illustrative reference to Cuba to assess how legal principles in respect of human rights and humanitarian law might be engaged. Two factors have determined these states as appropriate. At the time of writing, each state is subject to a series of UCMs imposed primarily by the US. By and large, the sanctions are framed as being in response to breaches by the target state of rights obligations towards its people.

The IHL framework under the Hague Conventions, Geneva Conventions and Additional Protocols was conceived with the conditions of armed conflict in mind. As such, those frameworks are not directly applicable to UCMs that are invoked as a peacetime measure. However, the use of UCMs has been said to amount to 'decentralised' economic warfare. ${ }^{34}$ There may be grounds to argue that imposing UCMs amounts to a form of war, albeit economic rather than military, so that the laws of war are, or ought to be, engaged. Even without pursuing this line of argument (there is not the scope to do so here ${ }^{35}$ ), there are strong arguments that IHL principles of necessity, distinction and proportionality can be aptly incorporated to the governance of UCMs. Indeed, according to Owen, these are principles that apply to economic sanctions in times of peace as well as times of war. ${ }^{36}$ For Reisman and Stevick, economic instruments 'should be tested rigorously' against IHL criteria before a decision to use or continue with their use is taken. ${ }^{37}$ They also point to the problematic use of UCMs because of 'their relative incapacity to discriminate between licit targets and ... their durable resultant collateral injuries, which persist long after the conclusion of the campaign'. ${ }^{38}$

Principles of distinction and proportionality are at the heart of customary international law, ${ }^{39}$ and various international instruments address distinction and proportionality in armed conflict. Under the Geneva Conventions Additional Protocol I, it is a grave breach to launch 'an indiscriminate attack affecting the civilian population or civilian objects in the knowledge

\footnotetext{
${ }^{34}$ Lowe and Tzanakopoulos (n 7) 10.

${ }^{35}$ See chs 1-3 for a full discussion of the arguments.

${ }^{36}$ Owen, 'The Limits of Economic Sanctions' (2012).

${ }^{37}$ Reisman and Stevick (n 1) 95.

38 ibid.

39 'IHL Database: Customary IHL', referring to Rule 14 Proportionality in Attack as a customary rule of IHL, and its presence in the Geneva Conventions as well as, eg, ICC Statute and the Convention on Certain Conventional Weapons, available at https://ihl-databases.icrc.org/customary-ihl/eng/docs/v2_rul_rule14.
} 
that such attack will cause excessive loss of life, injury to civilians or damage to civilian objects'. It is a war crime to intentionally launch an attack during international armed conflict 'in the knowledge that such attack will cause incidental loss of life or injury to civilians or damage to civilian objects' (ICC Rome Statute (1998), Article 8(2)(b)(iv).

The principle of proportionality has attracted significant attention as an appropriate means of monitoring the use and impact of UCMs. ${ }^{40}$ Proportionality is also at the heart of the law of countermeasures, although it has a separate meaning within that framework, whereby 'the potential effectiveness of the measure is not a fundamental criterion', but rather whether the measure is 'proportional to the original wrong', ${ }^{41}$ and adopted as a means of inducement, not punishment. ${ }^{42}$ The focus in this chapter is upon the meaning under IHL rather than the law of countermeasures. The principle of necessity under the Geneva and Hague Conventions has been descried as permitting the lawful use of force 'to overpower an enemy', ${ }^{43}$ but in a manner that is 'the least destructive measure capable of achieving its desired outcome'. ${ }^{44}$ Any losses, namely collateral damage, 'should not exceed the expected military advantage'. ${ }^{45}$ There now follows some consideration of how these fundamental IHL principles might be adopted and adapted to a governance regime for UCMs.

\section{A. Venezuela}

As noted above, the principles of necessity, proportionality and distinction require that action taken is necessary and proportionate to achieving the objective and distinguishes between the target and the civilian population. Satisfying these principles in relation to the imposition of UCMs against Venezuela is fraught with difficulty. There may be apparent grounds for coercive action to change state behaviour in response to significant state-sponsored human rights violations and government mismanagement. However, even though there may have been convincing arguments in favour of the principles of necessity, distinction and proportionality

\footnotetext{
${ }^{40}$ See, eg, J Gutmann, M Neuenkirch, F Neumeier and A Steinbach, 'Economic Sanctions and Human Rights: Quantifying the Legal Proportionality Principle', Research Papers in Economics 2/18 (2018) Universitat Trier, Fachbereich IV - Volkswirtschaftslehre, and O'Connell (n 2) 65-79.

${ }^{41}$ O'Connell (n 2) 65 79,78 and 77 respectively.

42 ARSIWA (n 32) para 6.

$43 \mathrm{~N}$ Tsagourias and A Morrison, International Humanitarian Law: Cases, Materials and Commentary (Cambridge University Press, 2018) 39.

${ }^{44}$ Owen (n 8) 118.

${ }^{45} \mathrm{R}$ Kolb and R Hyde, An Introduction to the International Law of Armed Conflicts (Hart Publishing, 2008) 132, cited by Owen (n 8) 118.
} 
having been met at the outset, when coercive action risks contributing to and/or causing a humanitarian crisis, this may come into doubt as the duration and intensity of the measures taken extends.

The US has had a series UCMs in force against Venezuela for over a decade. Sanctions in the mid-to-late 2000s related to anti-terrorism and drug trafficking measures whilst measures in response to anti-democratic actions, human rights violations and corruption followed in 2014, under Barack Obama's administration. ${ }^{46}$ More recent sanctions imposed by Canada and the EU, as well as the US, have been presented as a response to human rights abuses under Nicolás Maduro's rule and his government's mismanagement. ${ }^{47}$ Maduro and his government are no longer recognised by the internal community at large, and the country finds itself in an intractable position. It is heavily in debt to mainly US creditors; unable to restructure debt due to sanctions preventing dealing by US nationals with the Maduro regime; ${ }^{48}$ struggling to access its gold reserves in the UK; ${ }^{49}$ and there is a burgeoning humanitarian catastrophe exacerbated by an inability to trade with and import food and medical supplies from numerous countries, ${ }^{50}$ and further worsened by the COVID-19 pandemic. ${ }^{51}$

The cause of Venezuela's socioeconomic crisis is complex. Whilst the imposition of UCMs and their consequences may have played a significant role, other domestic and global factors have been instrumental. As an oil-producing and -exporting country, the Venezuelan economy suffered due to the global fall in oil prices in 2008 , and recession followed. ${ }^{52}$ By

\footnotetext{
${ }^{46}$ Congressional Research Service, 'Venezuela: Overview of U.S. Sanctions' 22 January 2020, available at fas.org/sgp/crs/row/IF10715.pdf.

47 EU $\quad$ Sanctions $\quad$ Map: Venezuela, available at www.sanctionsmap.eu/\#/main/details/44/?search=\%7B $\% 22$ value $\% 22: \% 22 \% 22, \% 22$ searchType $\% 22: \% 7 B \% 7 D$ \%7D. The Government of Canada imposed targeted asset freezes and prohibitions on dealing against named individuals within the Maduro regime in response to the Maduro Government's 'systemic erosion of Venezuela's democratic institutions and its grave human rights abuses' and pursuant to a 2017 Association between the US and Canada, 'Canadian Sanctions Related to Venezuela' Government of Canada, available at www.international.gc.ca/world-monde/international_relationsrelations_internationales/sanctions/venezuela.aspx?-̄ang=eng.

48 Jo Gordon, 'Off Target: How US Sanctions are crippling Venezuela' (2018) 145 Commonwealth Foundation 12.

${ }^{49}$ The "Maduro Board" of The Central Bank of Venezuela (Appellant) v The "Guaidó Board" of The Central Bank of Venezuela (Respondent) [2020] EWCA Civ 1249 (permission to appeal was granted by the UK Supreme Court to the Respondent in December 2020).

${ }^{50}$ M Weisbrot and J Sachs, 'Economic Sanctions as Collective Punishment: The Case of Venezuela' (Center for Economic and Policy Research 2019), available at cepr.net/images/stories/reports/venezuela-sanctions-201904.pdf.

${ }^{51}$ Human Rights Watch, 'Venezuela: Urgent aid needed to combat Covid-19' (26 May 2020), available at www.hrw.org/news/2020/05/26/venezuela-urgent-aid-needed-combat-covid-19.

${ }^{52} \mathrm{M}$ Weisbrot and R Ray, 'Update on the Venezuelan Economy' (Center for Economic and Policy Research, 2010) 4, available at cepr.net/documents/publications/venezuela-2010-09.pdf.
} 
2014, the Venezuelan economy was in a 'free fall' crisis and burdened by significant debt. ${ }^{53}$ Following democratic elections in December 2015, a coalition of opposition parties won a majority in the National Assembly. ${ }^{54}$ President Maduro responded in January 2016 by declaring a national emergency and began to rule by decree, dismantling the powers of the National Assembly along the way. ${ }^{55}$ As a result, over the course of the next 18 months a number of countries refused to recognise the legitimacy of Venezuela's National Constituent Assembly and its decisions. ${ }^{56}$ Part of the response of those countries was to impose sanctions in the form of targeted economic UCMs to bring Maduro and his government to heel.

\section{i. Determining Necessity}

Alleged human rights violations committed by the Maduro-led Venezuelan Government and those in public office are the subject of a number of matters under investigation by various bodies including the International Labor Organization (ILO), the ICC and the Human Rights Council. The global focus on the human rights situation in Venezuela may well be used as evidence of the necessity for intervention by the international community, but whether UCMs are the appropriate and necessary form of intervention would require balance against principles of proportionality and distinction. Furthermore, UCMs should be used to effect change in state practice. Resorting to UCMs before and/or during formal investigations by bodies such as the ILO, the ICC and the Human Rights Council has the potential to undermine the purpose of those bodies and amount to arbitrary unilateral action without the consent of the international community, perceived as a form of punishment and/or as a tool to promote regime change. With the principle of necessity in mind, this section briefly summarises those matters before the ILO, ICC and Human Rights Council.

Following submission of a complaint by workers unions to the ILO in 2015 and a lack of response from the Government of Venezuela, an ILO Commission of Inquiry (CoI) was convened in March 2018 to progress the matter further. ${ }^{57}$ The CoI reported in September 2019,

\footnotetext{
${ }^{53}$ Gordon, 'Off Target' (2018).

54 Government of Canada, 'Canadian Sanctions related to Venezuela', available at www.international.gc.ca/world-monde/international_relationsrelations_internationales/sanctions/venezuela.aspx?lang=eng.

55 ibid.

${ }^{56} \mathrm{~S}$ Brodzinksy and D Boffey, '40 countries protest Venezuela's new assembly amid fraud accusations' The Guardian (2 August 2017), available at www.theguardian.com/world/2017/aug/02/venezuela-voting-fraudcorruption-allegations-protests.

${ }^{57}$ ILO, 'For national reconciliation and social justice in the Bolivarian Republic of Venezuela', Report of the Commission of Inquiry appointed under Art 26 of the Constitution of the International Labour Organization to
} 
finding the Government to be in breach of its ILO convention obligations. It cited institutions and practices that were prejudicial to 'the existence and action of free and independent employers' and workers' organizations and the development of social dialogue in good faith in a climate of trust and mutual respect'. ${ }^{58}$ Allegations included murder and acts of physical aggression against trade union leaders and members and employer representatives, arbitrary detention, interference, control and favouritism. ${ }^{59}$ Following its investigations, the CoI recommended an 'immediate cessation of all acts of violence, threats, persecution, stigmatization, intimidation or other forms of aggression' against relevant persons and organisations, and 'the adoption of measures to ensure that such acts do not recur in future'.

The CoI's findings were reported in October 2019 with an implementation deadline for recommendations being no later than 1 September $2020 .{ }^{60}$ By this time, UCMs had been in full force against Venezuela for some years. Just prior to the CoI's findings, in September 2019, the Human Rights Council resolved to establish an independent international fact-finding mission to 'investigate extrajudicial executions, enforced disappearances, arbitrary detentions and torture and other cruel, inhumane or degrading treatment since 2014 , with a view to ensuring full accountability for perpetrators and justice for victims' ${ }^{61}$ This decision followed a report by the High Commissioner for Human Rights based upon 558 interviews, 159 meetings and documentary analysis. ${ }^{62}$

Arguably, the Human Rights Council has been slow to take action in response to the human rights situation in Venezuela. This might, in part, be due to the presence of Venezuela on the Human Rights Council's membership since 2015. ${ }^{63}$ Before the Human Rights Council's

examine the observance by the Government of the Bolivarian Republic of Venezuela of the Minimum WageFixing Machinery Convention, 1928 (No 26), the Freedom of Association and Protection of the Right to Organise Convention, 1948 (No 87), and the Tripartite Consultation (International Labour Standards) Convention, 1976 (No 144) (ILO, 2019).

58 ibid, ch 7 .

59 ibid, ch 7, para 365.

60 ibid, Summary.

61 UNHRC, 'Human rights situations that require the Council's attention' (24 September 2019) A/HRC/42/L.4/Rev.1, para 24.

62 OHCHR Report, 'Human rights in the Bolivarian Republic of Venezuela' (05 July 2019) A/HRC/41/18, paras 6-7.

${ }^{63}$ Venezuela has been a member of the Human Rights Council since January 2013. Its membership was renewed for the period 2015-18 and the country was then re-elected in 2019, with its current membership coming to an end in 2022; see https://www.ohchr.org/EN/HRBodies/HRC/Pages/PastMembers.aspx and www.ohchr.org/EN/HRBodies/HRC/Pages/CurrentMembers.aspx respectively. 
decision to establish an independent fact-finding mission, ${ }^{64}$ reports and evidence of state repression caused the ICC Prosecutor in February 2018 to open a preliminary investigation into crimes allegedly committed in Venezuela 'since at least April 2017 in the context of demonstrations and related political unrest' ${ }^{65}$ Later that year, in September 2018, a referral was made to the ICC by a number of states parties (Argentina, Canada, Colombia, Chile, Paraguay and Peru) against Maduro and his government, requesting an investigation into crimes against humanity. ${ }^{66}$

Those states parties, save for Canada and Paraguay, are arrival and/or destination countries for Venezuelan refugees. ${ }^{67}$ The refugee crisis has brought its own pressures to bear on those states and challenges in respect of the resurgence of paramilitary activity and the presence of organised crime and trafficking through and along Venezuela's porous border. ${ }^{68}$ The Latin-American states making the referral are also in receipt of US development aid, and may have geopolitical and diplomatic reasons for making a referral to the ICC that would appease the US, although for most of these states aid was reduced in 2019, sometimes significantly so. ${ }^{69}$ Indeed, it would seem that recourse to the ICC is highly politicised with the Maduro Government making its own request in early 2020 for the ICC to investigate US sanctions as crimes against humanity. ${ }^{70}$

The matter is further complicated when reviewing the political rhetoric that was employed by Trump and his administration, which calls into question the motivation for imposing UCMs and casts doubt upon their necessity. The US based Center for Economic Policy and Research (CEPR) highlights comments by Mike Pompeo, the then US Secretary of

\footnotetext{
${ }^{64}$ UNHRC Res 45/L.43/Rev.1 (2020) 'Situation of human rights in the Bolivarian Republic of Venezuela' (1 October 2020) A/HRC/45/L.43/Rev.1, the mandate of the mission was extended for a further two years.

${ }^{65}$ International Criminal Court, 'Statement of the Prosecutor of the International Criminal Court, Fatou Bensouda, on opening Preliminary Examinations into the situations in the Philippines and in Venezuela' (8 February 2018), available at www.icc-cpi.int/Pages/item.aspx?name=180208-otp-stat.

${ }^{66}$ International Criminal Court Preliminary examination: Venezuela I, available at www.icc-cpi.int/venezuela.

67 ACAPS Thematic Report, 'Venezuela Humanitarian Crisis' (23 May 2018) 3-6, available at reliefweb.int/sites/reliefweb.int/files/resources/20180523_acaps_thematic_report_humanitarian_crisis_in_venez uela.pdf.

68 ibid, 11.

${ }^{69}$ Congressional Research Service 'U.S. Foreign Assistance to Latin America and the Caribbean: FY2019 Appropriations' (1 March 2019), available at fas.org/sgp/crs/row/R45547.pdf.

${ }^{70}$ A Rizvi, 'Venezuela Foreign Minister asks ICC to investigate US sanctions as crimes against humanity' Jurist (14 February 2020), available at www.jurist.org/news/2020/02/venezuela-foreign-minister-asks-icc-toinvestigate-us-sanctions-as-crimes-against-humanity.
} 
State, in March 2019 that give cause to question the motivation for US involvement in Venezuela and the use of UCMs. Pompeo is reported as saying:

Well, we wish things could go faster, but I'm very confident that the tide is moving in the direction of the Venezuelan people and will continue to do so. It doesn't take much for you to see what's really going on there. The circle is tightening, the humanitarian crisis is increasing by the hour. I talked with our senior person on the ground there in Venezuela last night ...

You can see the increasing pain and suffering that the Venezuelan people are suffering from. [emphasis added] ${ }^{71}$

CEPR's analysis is that these comments demonstrate the humanitarian crisis is not solely the result of the economic policies of the Venezuelan Government over a prolonged period of time, nor simply collateral damage, but is "part of the strategy to topple the government' ${ }^{72}$ Furthermore, CEPR refers to comments made by the US administration that betray a broader strategy of appropriating Venezuela's oil. ${ }^{73}$ For CEPR, there are grounds to argue a breach of Articles 19 and 20 of the Organization of American States (OAS) Charter. Article 19 enshrines the principle of non-interference, prohibiting 'not only armed force but also any other form of interference or attempted threat against the personality of the State or against its political, economic, and cultural elements'. Article 20 refers to coercive measures, whereby: 'No State may use or encourage the use of coercive measures of an economic or political character in order to force the sovereign will of another State and obtain from it advantages of any kind'.

Venezuela remains a member of the OAS, despite reports in April 2017 of its proposed withdrawal. ${ }^{74}$ However, its membership relates to the interim government of Juan Guaidó, which is supported by the US and others, rather than the presidential government of Maduro. ${ }^{75}$ The US is also a long-standing member of the OAS. Given that Venezuela's membership is recognised by a government led by Guaidó, a close ally to the US, it is unlikely that any action would be sought under the OAS Charter against the US, unless it was possible for Maduro's government to secure standing. Even so, statements made by Trump, Pompeo and others could well be used as evidence to undermine claims by the US that the use of far reaching UCMs was necessary and proportionate.

\footnotetext{
${ }^{71}$ Weisbrot and Sachs, 'Economic Sanctions as Collective Punishment' (2019) 5.

72 ibid, 5.

73 ibid, 18.

${ }^{74}$ ACAPS (2018) 7, citing BBC News, 'Venezuela to withdraw from OAS as deadly protests continue' (27 April 2017), available at www.bbc.co.uk/news/world-latin-america-39726605.

${ }^{75}$ OAS Member States: www.oas.org/en/member_states/member_state.asp?sCode=VEN.
} 


\section{ii. Determining Proportionality and Distinction}

There is a lack of consensus that economic sanctions, whether unilateral or multilateral, succeed in reducing the human rights abuses by governments in the target state. Indeed, the indication is that such measures intensify and worsen the human rights situation. ${ }^{76}$ This of itself might be sufficient to cast doubt upon imposing UCMs in compliance with the principles of proportionality and distinction. Nonetheless, in 2019 the US imposed additional steps to block property of the Government of Venezuela and US persons purchasing or using Venezuelan government debt as collateral due to human rights abuses and 'ongoing attempts to undermine Interim President Juan Guaido and the Venezuelan National Assembly's exercise of legitimate authority in Venezuela'. ${ }^{77}$ The US has firmly placed responsibility for 'the deepening humanitarian crisis in Venezuela' with Maduro's regime. ${ }^{78}$ Elsewhere, UCMs are said to be the cause of the 'inability of the government to function'. ${ }^{79}$

Unsurprisingly, US motives have attracted scrutiny, suggesting an underlying agenda of regime change rather than purported protection for the people of Venezuela. ${ }^{80}$ There is a danger, as noted by Livingstone Sewanyana, Independent Expert on the Promotion of a Democratic and Equitable International Order (appointed as part of the Human Rights Council's Special Procedures), that 'In order to discredit selected governments, failures in the field of human rights are maximized so as to make violent overthrow more palatable. Human rights are being "weaponized" against rivals' ${ }^{81}$ Weaponising rights and causing injury beyond the named targets of the measures calls into question proportionality and distinction.

\footnotetext{
${ }^{76}$ D Peksen, 'Better or Worse? The Effect of Economic Sanctions on Human Rights' (2009) 46 Journal of Peace Research 59, 68, 73-74.

${ }^{77}$ US Treasury, 'Blocking Property of the Government of Venezuela', Executive Order 13884 (5 August 2019), available at https://home.treasury.gov/policy-issues/financial-sanctions/sanctions-programs-and-countryinformation/venezuela-related-sanctions.

${ }^{78}$ US Treasury, 'Imposing Additional Sanctions With Respect to the Situation in Venezuela', Executive Order 13808 (24 August 2017), available at https://home.treasury.gov/policy-issues/financial-sanctions/sanctionsprograms-and-country-information/venezuela-related-sanctions.

${ }^{79}$ Gordon (n 48).

${ }^{80} \mathrm{P}$ Torres, J Borger, J Parkin Daniels and T Phillips, 'The plot that failed: how Venezuela's “uprising” fizzled', The Guardian (3 May 2019); see also comments made by Mike Pompeo, above in this chapter.

${ }^{81}$ UNHRC, 'Report of the Independent Expert on the promotion of a democratic and equitable international order on his mission to the Bolivarian Republic of Venezuela and Ecuador' (3 August 2018) A/HRC/39/47/Add.1, para 29 available at https://documents-ddsny.un.org/doc/UNDOC/GEN/G18/239/31/PDF/G1823931.pdf?OpenElement.
} 
Whilst EU and Canadian measures against Venezuela are narrow in focus, ${ }^{82}$ the broad and far-reaching impact of US UCMs against Venezuela suggests a failure to adhere to principles of proportionality and distinction. There are reports of large numbers of the population being denied access to medical, fuel and food essentials, prompting mass migration out of the country. ${ }^{83}$ This indicates violation of the principle of distinctiveness - whilst the UCMs are supposedly targeted against named companies and individuals, the impact is on the most vulnerable populations without access to financial reserves and at the mercy of alternative unregulated markets to secure medical and other essential supplies. ${ }^{84}$

In addition, there are concerns that civilian populations are suffering from starvation. One report estimates that between 2017 and 2018 there were 40,000 deaths and widespread starvation due to UCMs, prompting allegations of collective punishment. ${ }^{85}$ In August 2018, following his visit earlier that year to Venezuela, Sewanyana found that UCMs by the US, Canada and the EU had 'directly and indirectly aggravated the shortages in medicines such as insulin and anti-retroviral drugs' ${ }^{86}$ That sanctions had caused delays in distribution had, according to Sewanyana, contributed 'to many deaths' and should be investigated as a crime against humanity by the ICC (under Article 7 of the Rome Statute), but that 'the geopolitical submissiveness of the Court may prevent this' ${ }^{87}$ Interestingly, the Venezuelan Government, as led by Maduro, rebutted the contents of a report by the High Commissioner for Human Rights that found the supplies in hospitals and their capacity seriously wanting, a response that could be used to undermine the strength of arguments that the impact of UCMs on the Venezuelan healthcare system is in breach of IHL principles. ${ }^{88}$

The UN World Food Programme reported in 2019 that approximately one-third of the population in Venezuela was either moderately or severely food-insecure, with a lack of dietary

\footnotetext{
${ }^{82}$ EU measures include an embargo on the sale of arms and equipment for internal repression and asset freezes for 25 named individuals: Council of the European Union, 'Venezuela: Council renews sanctions until 14 November 2020', Press Release (11 November 2019), available at www.consilium.europa.eu/en/press/pressreleases/2019/11/11/venezuela-council-renews-sanctions-until-14-november-2020. Canadian measures include asset freezes and dealings prohibitions with listed persons / persons acting on their behalf in accordance with an agreement it has with the US; see www.international.gc.ca/world-monde/international_relationsrelations_internationales/sanctions/venezuela.aspx?lang=eng.

${ }^{83}$ Weisbrot and Sachs (n 50) 2.

${ }^{84}$ UNHRC Report (n 81) para 36.

${ }^{85}$ Weisbrot and Sachs (n 50) 2.

${ }^{86}$ UNHRC Report (n 81).

87 ibid, para 36.

${ }^{88}$ The response describes a well-resourced healthcare system with medical supplies being well stocked and available, 'Venezuela comments on UN's 'human rights' report' The Communists (19 July 2019), available at thecommunists.org/2019/07/19/news/venezuela-comments-un-human-rights-report.
} 
diversity being 'of major concern'. ${ }^{89}$ The report refers to depleting coping mechanisms amongst families that have used savings to buy food and to a deterioration in basic services (water, sanitation, housing, electricity, cooking facilities). ${ }^{90}$ Yet food insecurity has plagued the people of Venezuela for some time. ${ }^{91}$ Attributing food and other insecurities to UCMs would be subject to further investigation. If it was found that UCMs increased food, energy and/or medical insecurity there would be grounds upon which to suggest that both proportionality and distinction were in breach.

Compliance with the principles of proportionality and distinction are also called into question by the extraterritorial scope of the US's UCMs, which significantly interferes with world trade and inter-state trading relationships. The US has specifically threatened sanctions against India if it continues to purchase oil from Venezuela. ${ }^{92}$ By seriously limiting access to trade, extraterritoriality has been cited as contributing to Venezuela's move from high inflation to hyper-inflation, and putting vulnerable populations at greater risk by exacerbating the lack of access to essential services and supplies such as food, medicine and energy. ${ }^{93}$

The issues raised in this section are not peculiar to Venezuela. The US sanctions regime against Cuba has been running in some form or another since $1960 .{ }^{94}$ Alleged consequences of the UCMs against Venezuela mirror, for example, reports of the severe and detrimental impact of US unilateral sanctions against Cuba and its public health infrastructure, supplies and outcomes. ${ }^{95}$ The effects of sanctions have also been described in terms of gross violations of humanitarian principles. Following the US's escalation in UCM pressure against Cuba, the Cuban Foreign Minister stated in 2019 that, 'the blockade has caused incalculable humanitarian damages. It is a flagrant, massive and systematic violation of human rights'. He described the blockade as an act of genocide pursuant to Articles II(b) and (c) of the Convention on the

\footnotetext{
${ }^{89}$ OHCHA World Food Programme, 'WFP Venezuela Food Security Assessment Main Findings: Data Collected between July and September 2019' (23 February 2020), available at reliefweb.int/report/venezuela-bolivarianrepublic/wfp-venezuela-food-security-assessment-main-findings-data.

90 ibid.

${ }^{91}$ Associated Press in Caracas, 'One in three Venezuelans not getting enough to eat, UN finds', The Guardian (24 February 2020), available at www.theguardian.com/world/2020/feb/24/venezuela-hungry-food-insecure-unworld-food-program.

92 Weisbrot and Sachs (n 50) 2.

93 ibid, 19-21.

${ }^{94}$ CM DeMelfi, 'Nothing but the Facts: An In-Depth Analysis of the Effects of Economic Sanctions Against Cuba' (2006) 5 Journal of International Business Law 146.

${ }_{95}$ Garfield and Santana (n16), 'The Impact of the Economic Crisis' (1997).
} 
Prevention and Punishment of the Crime of Genocide (1948), stating 'there is not one single Cuban family that has not suffered the consequences of this' ${ }^{96}$

In contrast, there is scholarship that celebrates the relative success of Cuba's response to US sanctions. Cuba has succeeded, despite the crippling effect of the sanctions on its trade with the US, to function and manage its public services, albeit at times at reduced capacity, and by taking measures to fight corruption in public office, ${ }^{97}$ as well as diversifying its trading relations. ${ }^{98}$ Even so, it remains that despite having been imposed for over five decades, US sanctions have failed to achieve the US's ultimate objective of regime change, ${ }^{99}$ and the duration and intensity of the UCMs surely calls into question their necessity, proportionality and distinction.

\section{B. Iran}

The US sanctions regime against Iran first began in 1979 in the form of a blocking order against all property and interests in property of the Iranian Government. ${ }^{100}$ UCMs were used to impose further pressure in the early 2010 s by the UN and the EU as well as the US in response to Iran's nuclear ambitions and human rights violations. ${ }^{101}$ The primary objective of EU measures was couched in human rights terms. Asset freezes and travel restrictions were introduced against those involved in 'grave human rights violations in the repression of peaceful demonstrators, journalists, human rights defenders, students or other persons who speak up in defense [sic] of their legitimate rights'. ${ }^{102}$ In addition, sanctions prohibiting access to equipment used for

\footnotetext{
${ }^{96}$ UNGA, 'General Assembly Adopts Annual Resolution Calling on United States to End Embargo against Cuba, as Brazil Rejects Text for First Time' (7 November 2019) Press Release.

${ }^{97} \mathrm{M}$ Hove, E Ndawana and MA Nhemachena, 'How Cuba survived sanctions and the lessons for Zimbabwe' (2020) 24(2) Jadavpur Journal of International Relations 1, 8.

${ }^{98}$ UNGA Res $73 / 8$ (2018), 'Necessity of ending the economic, commercial and financial embargo imposed by the United States of America against Cuba' (1 November 2018) UN Doc A/RES/73/8, see statement by Equatorial Guinea.

${ }^{99}$ Hove, Ndawana and Nhemachena, 'How Cuba survived sanctions' (2020) 8.

${ }^{100}$ US Treasury, 'Blocking Iranian Government Property', Executive Order 12170 (14 November 1979), available at home.treasury.gov/system/files/126/12170.pdf. For current and historical details of US sanctions against Iran, see US Department of the Treasury Resource Centre at https://home.treasury.gov/policy-issues/financialsanctions/sanctions-programs-and-country-information/iran-sanctions.

${ }^{101}$ For an overview of the history of US sanctions against Iran, see Congressional Research Service, Iran Sanction (updated July 2020), at fas.org/sgp/crs/mideast/RS20871.pdf.

102 EU Sanctions map: Iran, www.sanctionsmap.eu/\#/main/details/17/?search=\%7B\%22value\%22:\%22\%22,\%22searchType $\% 22: \% 7 \mathrm{~B} \% 7 \mathrm{D}$ $\% 7 \mathrm{D}$.
} 
internal repression and telecommunications equipment were imposed. Restrictions could be extended to those:

[C]omplicit in or responsible for directing or implementing grave violations of the right to due process, torture, cruel, inhuman and degrading treatment, or the indiscriminate, excessive and increasing application of the death penalty, including public executions, stoning, hangings or executions of juvenile offenders in contravention of Iran's international human rights obligations. ${ }^{103}$

\section{i. Determining Necessity and Proportionality}

The impact of sanctions is said to have played a part in prompting Iran to enter the Joint Comprehensive Plan of Action (JCPOA), ${ }^{104}$ which led to the lifting of the majority of the UCMs (and UN sanctions) that had been imposed in the early 2010s. ${ }^{105}$ This change in Iranian state practice could indicate that the imposition of UCMs in the early 2010 s was a necessary and proportionate means of affecting a change in the actions of Iran's ruling regime. However, in May 2018 the US withdrew from the JCPOA and reimposed UCMs against Iran. This was in response to Iran publicly stating it would deny the International Atomic Energy Agency access to military sites and, two years earlier, having twice violated the JCPOA's heavy-water stockpile limits. The US declared the reimposed sanctions to be the 'toughest U.S. sanctions ever imposed on Iran', designed to 'target critical sectors of Iran's economy, such as the energy, shipping and shipbuilding, and financial sectors', with the US promising to engage 'in a campaign of maximum financial pressure on the Iranian regime ... to enforce aggressively these sanctions that have come back into effect'. ${ }^{106}$

Reimposed UCMs included blocking sanctions: to prevent Iran from purchasing US bank notes or precious metals; against certain Iranian persons, for example, to prohibit any transactions in foreign exchange and transfers of credit or payments between financial institutions or by, through, or to, any financial institution subject to the jurisdiction of the US and in which the sanctioned person has any interest; against Iran's energy, shipping, and

\footnotetext{
103 ibid.

${ }^{104}$ See UNSC Res 2231 (25 July 2015) UN Doc S/RES/2231/2015, Joint Comprehensive Plan of Action (JCPOA), the nuclear agreement between Iran, and the permanent five members of the UNSC, plus Germany (P5+1), see European Council, 'Joint Comprehensive Plan of Action and restrictive measures', available at www.consilium.europa.eu/en/policies/sanctions/iran/jcpoa-restrictive-measures.

${ }^{105}$ M Nesbitt, 'Canada's Unilateral Sanctions Regime Under Review: Extraterritoriality Human Rights Due Process and Enforcement in Canada's Special Economic Measures Act' (2016) 48 Ottawa Law Review 507, 517. 106 US Treasury, 'Re-imposition of the sanctions on Iran that had been lifted or waived under the JCPOA', (Resource Centre, 4 November 2018), available at https://home.treasury.gov/policy-issues/financialsanctions/sanctions-programs-and-country-information/iran-sanctions/re-imposition-of-the-sanctions-on-iranthat-had-been-lifted-or-waived-under-the-jcpoa.
} 
shipbuilding sectors and port operators, measures to prevent trade with the automotive and petroleum sector, and more. ${ }^{107}$ In addition, sanctions were imposed against both US and nonUS persons dealing with the Iran's civil aviation industry. ${ }^{108}$

The EU has expressed its view of the extraterritorial aspect of the UCMs by amending its Blocking Regulation to circumvent the extraterritorial scope of US sanctions. ${ }^{109}$ This response calls into question the proportionality of the UCMs imposed by the US and is consistent with the EU's position on this in the past. In 1996, the EU filed a complaint with the World Trade Organization (WTO) against the extraterritorial reach of US sanctions against Cuba, Iran and Libya contained in the US's Helms-Burton and D'Amato-Kennedy Acts. ${ }^{110}$ It withdrew the complaint for further consideration, proceeding instead to pass the Blocking Regulation to prohibit EU Member State compliance with the extraterritorial sanctions, and to protect the interests of EU Member States that suffered loss as a result. ${ }^{111}$ The EU has yet, however, to enforce the Blocking Regulation, and so whilst it is 'symbolically important', it is 'largely seen as toothless'. 112

The EU has, however, reiterated its position in respect of the secondary aspects of the sanctions against Cuba. ${ }^{113}$ This reflects the almost universal position of the international community as illustrated by the voting on a General Assembly resolution in 2018 on ending US sanctions against Cuba, where 189 states voted in favour of the resolution with only the US and Israel voting against (and with no abstentions). ${ }^{114}$ Furthermore, France, Germany and the

\footnotetext{
${ }^{107}$ US Treasury, 'Re-imposing certain sanctions with respect to Iran', Executive Order 13846 (6 August 2018), available at https:/home.treasury.gov/policy-issues/financial-sanctions/sanctions-programs-and-countryinformation/iran-sanctions.

${ }^{108}$ US Treasury, 'Deceptive Practices by Iran with respect to the Civil Aviation Industry' Iran-Related Civil Aviation Industry Advisory (23 July 2019), available at https://home.treasury.gov/policy-issues/financialsanctions/recent-actions/20190723.

109 Commission Delegated Regulation (EU) 2018/1100 (7 August 2018) and Guidance Note, 'Questions and Answers: adoption of update of the Blocking Statute' (2018/C 277 I/03), available at eur-lex.europa.eu/legalcontent/EN/TXT/?uri=uriserv:OJ.CI.2018.277.01.0004.01.ENG\&toc=OJ:C:2018:277I:TOC\#ntr1CI2018277EN.01000401-E0001.

${ }^{110}$ PK Chudzicki, 'The European Union's Response to the Libertad Act and the Iran-Libya Act: Extraterritoriality without Boundaries' (1997) 28 Loyola University Chicago Law Journal 505, 506.

${ }^{111}$ EC Council Regulation (EC) No 2271/96, 'Protecting against the effects of the extra-territorial application of legislation adopted by a third country, and actions based thereon or resulting therefrom' (22 November 1996).

112 IJazairy, 'Unilateral economic sanctions, International Law and Human Rights' (2019) 33 Ethics and International Affairs, 291, 299.

${ }^{113}$ Europa 'The European Union and Cuba held Dialogue on Unilateral Coercive Measures', Press Release (30 November 2019), available at eeas.europa.eu/headquarters/headquarters-homepage/71260/european-union-andcuba-held-dialogue-unilateral-coercive-measures_en.

${ }^{114}$ UNGA Res $73 / 8$ 'Necessity of ending the economic, commercial and financial embargo imposed by the United States of America against Cuba' A/73/L.3 (1 November 2018) 19, available at undocs.org/en/A/73/PV.30.
} 
UK have taken direct action to bypass extraterritorial constraints to establish the Instrument in Support of Trade Exchanges (INSTEX) to allow EU economic entities to trade legitimately with Iran. ${ }^{115}$ The first transaction via this mechanism took place in April 2020, enabling the sale of medical supplies from the EU to Iran. ${ }^{116}$

In defiance of the US's imposition of extraterritorial UCMs, this is a bold step taken to demonstrate EU commitment to the JCPOA with Iran. ${ }^{117}$ It indicates a refusal to comply with US secondary measures, suggesting those measures are unnecessary, disproportionate and unlawful. Indeed, it has been said that it is 'an emergent (if not already established) rule of customary international law' that UCMs 'with secondary or extraterritorial effects, "which affect the sovereignty of other States, the legitimate interests of entities or persons under their jurisdiction and the freedom of trade and navigation" are almost universally seen by the international community as unlawful. ${ }^{118}$

There would appear to be a growing consensus that 'sanctions that extend beyond national borders, and which seek to block a country's trade altogether, amount to economic warfare against civilians' where people 'die, but from lack of food and medicine, rather than from explosive devices'. ${ }^{119}$ However, and despite the signal the amendment of the EU Blocking regulation (a regulation that also applies to Cuba) and establishment of INSTEX sends, as Joy Gordon comments, 'for banks, shipping companies, insurers, technology companies, or the energy industry, the bottom line is that no one can risk losing access to U.S. markets, regardless of whether U.S. sanctions accord with international law'. ${ }^{120}$ The continued dominance of the US in terms of global trade means that private entities are likely to comply with the extraterritorial scope of sanctions, deepening the negative human rights and humanitarian effects of UCMs.

\footnotetext{
115 UKFCO 'Iran and INSTEX: E3 statement', Press Release (20 November 2019), available at www.gov.uk/government/news/e3-statement-on-iran-and-instex.

116 A Brzozowski, 'EU's INSTEX mechanism facilitates first transaction with pandemic-hit Iran' Euractiv (1 April 2020), available at www.euractiv.com/section/global-europe/news/eus-instex-mechanism-facilitates-firsttransaction-with-pandemic-hit-iran, and 'EU sells medical goods via INSTEX' Financial Tribune (3 April 2020), available at financialtribune.com/articles/business-and-markets/102669/eu-sells-medical-goods-via-instex.

${ }^{117}$ E Geranmayeh and E Batmanghelidj, 'Trading with Iran via the special purpose vehicle: How it can work' European Council on Foreign Relations (7 February 2019), available at www.ecfr.eu/article/commentary_trading_with_iran_special_purpose_vehicle_how_it_can_work.

118 Jazairy, 'Unilateral economic sanctions' (2019) 294, citing UNGA Res 73/8 (2018), 'Necessity of ending the economic, commercial and financial embargo imposed by the United States of America against Cuba' 01 November 2018) UN Doc A/RES/73/8.

119 OHCHR (n 14).

${ }^{120}$ Gordon (n 48).
} 


\section{ii. Determining Distinction}

In the midst of the sanctions against Iran in the first half of the $2010 \mathrm{~s}$, concerns were raised of another pending humanitarian disaster due to a lack of medical and laboratory supplies. As Ali Gorji explains, whilst the sanctions did not make direct reference to medical supplies, the flow into the country of medical supplies was interrupted due to 'difficulties in holding license [sic] for export of medicine, financial transaction, and shipment as well as fear of possible U.S. sanction by pharmaceutical companies and international banks'. ${ }^{121}$ Studies indicate that during that period, the significant negative impact upon health and medical supplies affected the treatment of numerous conditions, including diabetes, cancer, asthma and pulmonary disease as well as anti-viral, anti-depressant drugs and medication and those related to transplants and more. ${ }^{122}$ In addition, one study concludes that indirect effects of UCMs include an increased presence of carcinogenic air pollution. ${ }^{123}$ These studies highlight detrimental consequences of UCMs beyond their named targets to the broader population, in breach of the principle of distinction.

Following the reintroduction by the US of UCMs in 2018, concerns were raised that although sanctions contained humanitarian exemptions, issues relating to international interbank transfers 'may make such exemptions inoperative'. ${ }^{124}$ Iran was swift to act in submitting an application to the ICJ in July 2018, alleging violations by the US of the Treaty of Amity, Economic Relations and Consular Rights (agreed between the two states in 1955). ${ }^{125}$ Iran included a request for 'provisional measures' to preserve its rights under the 1955 Treaty, pending the Court's final decision in the case. Finding that the US's obligations under the bilateral treaty were engaged, the ICJ unanimously ordered a number of provisional measures. These included that the US 'remove any impediments' to the free exportation to Iran of supplies

${ }^{121}$ A Gorji, 'Sanctions against Iran: The Impact on Health Services' (2014) 43 Iranian Journal of Public Health 381,381 .

122 S Setayesh and TK Mackey, 'Addressing the impact of economic sanctions on Iranian drug shortages in the joint comprehensive plan of action: promoting access to medicines and health diplomacy' (2016) 12 Global Health, available at doi.org/10.1186/s12992-016-0168-6.

${ }^{123}$ S Shahabi, H Fazlalizadeh, J Stedman, L Chuang, A Shariftabrizi and R Ram, 'The Impact of International Economic Sanctions on Iranian Cancer Healthcare' (2015) 119 Health Policy, 1309 refers to reduced access to refined oil due to the extraterritoriality of US sanctions led to Iran using outdated equipment and producing lower grade petroleum with an increased rate of benzine, a carcinogenic air pollutant, said to create a higher risk of cancer in Tehran in particular.

${ }^{124}$ OHCHR (n 14).

125 Alleged Violations of the 1955 Treaty of Amity, Economic Relations, and Consular Rights (Islamic Republic of Iran v United States of America), Request for the Indication of Provisional Measures, Order of 3 October 2018, available at ICJ, www.icj-cij.org/public/files/case-related/175/175-20181003-ORD-01-00-EN.pdf. 
for medicine and medical equipment, foodstuffs and agricultural commodity, and equipment and services necessary for the safety of civil aviation that were otherwise interrupted as a result of the reimposed sanctions. ${ }^{126}$ In doing so, the ICJ acknowledged the potential of economic sanctions to cause 'irreparable prejudice'.

The ICJ's court order and its recognition of the potential negative impact of US sanctions against Iran could well be used as evidence of a violation of both the principle of proportionality - whether such measures were proportionate in response to Iran's disengagement at that stage with the JCPOA, and the principle of distinction - because the effect of the measures would appear to go well beyond the named targets to impact a significant proportion of the civilian population. Action by the US since the ICJ's order suggests it is in breach of the Court Order, having implemented additional sanctions and having been slow to make changes with 'uncertain benefit' in respect of access to medical supplies and equipment. $^{127}$

\section{Conclusion}

Sanctions are silent killing, especially for those who are dealing with chronic diseases or emergency disorders; the needful are left abandoned. ${ }^{128}$

The arguments against the legality of UCMs are significant. Whilst their design has followed the Security Council's approach of using targeted sanctions, UCMs are unlawful being beyond the scope of the UN Charter, and as such are not subject to the authority of the Security Council. They undermine and contravene the principles of the multilateral trading system; studies indicate that UCMs are highly disruptive to supply chains of essential services and supplies and the capacity of the target state to trade. Consequently, their socioeconomic impact directly and indirectly causes gross human rights abuses and humanitarian suffering whilst, paradoxically, there is little evidence that UCMs succeed in meeting their stated objective.

There is not universal condemnation of the use and/or impact of UCMs. There is, unsurprisingly, a divide between those that situate the cause of the human rights and

\footnotetext{
${ }^{126} \mathrm{ibid}$, para 102. At the time of writing, proceedings on the merits of the case are suspended pending the outcome of preliminary objections by the US, ICJ Press Release No 2020/28, 21 September 2020, available at www.icjcij.org/public/files/case-related/175/175-20200921-PRE-01-00-EN.pdf.

${ }^{127} \mathrm{~J}$ Klingler, B Barnes and T Sepheri, 'Is the US in Breach of the ICJ's Provisional Measures Order in Alleged Violations of the 1955 Treaty of Amity?' (2020) 24(12) American Society of International Law.

128 Gorji, 'Sanctions against Iran' (2014) 381.
} 
humanitarian suffering with the government of those people, and those that attribute humanitarian crisis to states imposing UCMs. Both positions risk being politicised and polarised, failing to take account of complex historical, systemic and geopolitical factors. However, evidence from various studies and sources cited in this chapter indicates that the consequences of UCMs all too often adversely affect those suffering from the human rights abuses that sanctions are purportedly imposed to address. Furthermore, such evidence indicates that the sanctions often fail to be effective at securing their stated objective: a change in state behaviour.

Described as 'economic terrorism' ${ }^{129}$ and 'economic asphyxiation', ${ }^{130}$ the deployment of UCMs has been compared to 'medieval sieges of towns with the intention of forcing them to surrender'. ${ }^{131}$ The citing of human rights abuses by the target state as grounds for intervention by the imposing state has been portrayed as a veil for action driven by political ideology often to support regime change. ${ }^{132}$ Jorge Arreaza Montserrat, Venezuela's Minister for Foreign Affairs, has referred to the US's action against Cuba as 'imperial arrogance' amounting to collective punishment. ${ }^{133}$ In a similar vein, Iran's delegate before the UN said the US 'has been addicted to imposing unilateral sanctions when it comes to States that do not submit to, or follow, its contradictory and expansionist policies'. ${ }^{134}$

Former Special Rapporteur on UCMs, Idriss Jazairy, has called for the international community to give the 'form of warfare' meted through unilateral sanctions 'that relies on starvation and disease', the same concern as an armed conflict would warrant. ${ }^{135}$ As this contribution has demonstrated, the laws of war in relation to the principles of necessity, proportionality and distinction, and the prohibition of collective punishment, are apt for

\footnotetext{
129 Javad Zarif, Iranian Foreign Minister, quoted with reference to US sanctions against Iran, 'Trump orders tougher sanctions on Iran' The Financial Times (19 September 2019).

${ }^{130}$ UNHRC Report (n8 1) para 39 and 37 respectively.

131 ibid.

132 S Lee, 'Law and Development of Cuba under US-led Sanctions and its Implications for HR757' (2017) 24 Journal of International and US Committee of Foreign Relations 77; 'Understanding The Impact Of U.S. Policy Changes On Human Rights And Democracy In Cuba And U.S. Cuban Relations-The Way Forward', Hearings Before the US Senate Subcommittee on Western Hemisphere Transnational Crime, Civilian Security, Democracy, Human Rights, and Global Women's Issues, and The Committee On Foreign Relations United States Senate, 3 February 2015 and 20 May 2015, 3, available at www.govinfo.gov/content/pkg/CHRG114shrg96108/pdf/CHRG-114shrg96108.pdf.

${ }^{133}$ UNGA, 'General Assembly Adopts Annual Resolution Calling on United States to End Embargo against Cuba, as Brazil Rejects Text for First Time', Press Release (7 November 2019), available at www.un.org/press/en/2019/ga12212.doc.htm.

134 ibid.

135 OHCHR (n 14).
} 
application to the decision to impose and the continued use of UCMs. Yet, in taking this approach, there is an implicit acceptance of UCMs as a legitimate means of resolving interstate issues, which of itself is contrary to the position of certain states (see reference to China, India and Russia above, for example) and the Human Rights Council. Furthermore, just because those principles might be applied, it does not mean they can be easily satisfied.

Pursuant to the principle of distinction, attacks must not be directed against the civilian population. ${ }^{136}$ UCMs present a particular difficulty in satisfying this principle because there is an 'incapacity to discriminate between licit targets and because of their durable resultant collateral injuries, which persist long after the conclusion of the campaign in which they were deployed' ${ }^{137}$ Humanitarian and human rights protection is ostensibly incorporated into sanctions regimes via humanitarian exceptions designed to permit the safe passage of essential medical supplies, health services and food, etc into the target state. However, as noted, the lack of access to international interbank transfers and the extraterritorial reach of US sanctions has been cited as compromising access and capacity to trade in these supplies.

In addition, the prohibition of collective punishment broadly requires that a population should not be punished for acts of individuals that the population cannot be regarded as jointly and severally responsible for. ${ }^{138}$ Targeted UCMs are aimed at specific people and entities yet the failure to distinguish between the target and the general populace has been described at its most extreme as causing starvation and suffering tantamount to collective punishment. ${ }^{139}$ If UCMs are to be used as a means to effect change in state practice in compliance with IHL, their focus should be proportionate and distinctive in relation to that objective. One compelling recommendation is for a human rights impact assessment test to be conducted before implementing sanctions unilaterally, and to monitor on a regular basis the effects of the measures, including their adverse effect on human rights. ${ }^{140}$ This could include a "contextual inquiry' where the impact of potential UCMs is measured 'against the criteria of the international law of armed conflict and other relevant norms of contemporary international law

\footnotetext{
136 See, especially: Art 8(2)(e)(i), ICC Statute and Art 13, Additional Protocol II, Geneva Conventions, both applicable to non-international armed conflicts, and Art 48, Additional Protocol I, Geneva Conventions.

${ }^{137}$ Reisman and Stevick (n 1) 95.

${ }^{138}$ Art 50 of the Hague Convention IV: 'No general penalty, pecuniary or otherwise, shall be inflicted upon the population on account of the acts of individuals for which they cannot be regarded as jointly and severally responsible'. Similar provisions apply under the Geneva Conventions, eg dealing with the protection of prisoners of war.

139 Weisbrot and Sachs (n 50).

140 Jazairy (n112) 296.
} 
before a decision is made to initiate or to continue to apply them'. ${ }^{141}$ Without such an assessment being undertaken, the use of UCMs would be unlawful. ${ }^{142}$

In the meantime, the US maintains a robust approach seeking to undermine its adversaries using unilateral sanctions to full effect as demonstrated by the recent passing of the Ceasar Syrian Civil Protection Act 2019, although much of what is contained in this Act has been subject to sanctions for some time under Executive Orders introduced by the Obama administration. ${ }^{143}$ The 2019 Act encompasses regimes supporting Assad in Syria by citing human rights abuses in Syria as the basis for action so that, 'Instead of Iranian and Hezbollah actors looking like they are being targeted on political grounds, they now could be targeted on the basis that they are supporting the unprecedented human rights abuses in Syria'. ${ }^{144}$

Although there is evidence of a groundswell against the unilateral actions of the US with states taking action to defy the extraterritoriality of certain US economic sanctions (see the reference to INSTEX, the amended European Blocking Regulation, and recent Human Rights Council Resolutions, above), more decisive geopolitical action at an international level would be needed to police the use of UCMs. Despite growing calls by states, the Human Rights Council and Special Rapporteurs to refrain from imposing UCMs, it is unlikely that the US, and others, would desist. The US is the main champion of high intensity UCMs and under Donald Trump the US's exceptionalism approach to geopolitics arguably expanded, whilst engagement with international organisations such as the Human Rights Council and the World Health Organization contracted. It remains to be seen what strategy the US will adopt under a fresh, Joe Biden-led, administration.

\footnotetext{
${ }^{141}$ Reisman and Stevick (n 1) 132 and 95, respectively.

142 Reisman and Stevick (n 1) 132.

${ }^{143}$ D Stroul and K Bauer, 'The Caesar Act Comes Into Force (Part 1): Increasing the Assad Regime's Isolation', The Washington Institute (11 June 2020), available at https://www.washingtoninstitute.org/policyanalysis/caesar-act-comes-force-part-1-increasing-assad-regimes-isolation.

${ }^{144}$ Ibrahim Olabi, of the Syrian Legal Development Programme, quoted in M Chulov, 'US “Caesar Act” sanctions could devastate Syria's flatlining economy' The Guardian (12 June 2020), available at www.theguardian.com/world/2020/jun/12/us-caesar-act-sanctions-and-could-devastate-syrias-flatliningeconomy.
} 